\title{
Risk factors for retirement home COVID-19 outbreaks in Ontario, Canada: A population-level cohort study
}

Andrew P. Costa PhD ${ }^{1-6}$; Derek R. Manis MHSc ${ }^{1,6}$; Aaron Jones PhD ${ }^{1,5}$; Nathan M. Stall MD ${ }^{5,7-11}$; Kevin A. Brown MSc, PhD ${ }^{12,13}$; Veronique Boscart, RN, $\mathrm{PhD}^{4,14}$; Adriane Castellino MBA ${ }^{15}$; George A. Heckman MD, MSc ${ }^{4,16}$; Michael P. Hillmer MSc, PhD ${ }^{9,17}$; Chloe Ma MA ${ }^{15}$; Paul Pham B.Eng. ${ }^{15}$; Saad Rais, MSc ${ }^{17}$; Samir K Sinha MD, DPhil ${ }^{7-9,11}$; Jeffrey W. Poss PhD ${ }^{1,16}$

${ }^{1}$ Department of Health Research Methods, Evidence, and Impact, McMaster University, Hamilton, Canada

${ }^{2}$ Department of Medicine, McMaster University, Hamilton, Canada

${ }^{3}$ Centre for Integrated Care, St. Joseph's Health System, Hamilton, Canada

${ }^{4}$ Schlegel Research Institute for Aging, Waterloo, Canada

${ }^{5}$ Institute for Clinical Evaluative Sciences (IC/ES), Toronto, Canada

${ }^{6}$ Centre for Health Economics and Policy Analyses (CHEPA), St. Joseph's Health System, Hamilton, Canada

${ }^{7}$ Division of General Internal Medicine and Geriatrics, Sinai Health and University Health Network, Toronto, Canada

${ }^{8}$ Department of Medicine, University of Toronto, Toronto, Canada

${ }^{9}$ Institute of Health Policy, Management and Evaluation, University of Toronto, Toronto, Canada

${ }^{10}$ Women's College Research Institute, Women's College Hospital, Toronto, Canada

${ }^{11}$ National Institute on Ageing, Ryerson University, Toronto, Canada

${ }^{12}$ Infection Prevention and Control, Public Health Ontario, Toronto, Canada

${ }^{13}$ Dalla Lana School of Public Health, University of Toronto, Canada

${ }^{14}$ Conestoga College Institute of Technology and Advanced Learning

${ }^{15}$ Retirement Homes Regulatory Authority (RHRA)

${ }^{16}$ School of Public Health and Health Systems, University of Waterloo

${ }^{17}$ Capacity Planning and Analytics, Ontario Ministry of Health, Toronto, Canada

Corresponding author: Andrew P. Costa, PhD

Schlegel Chair in Clinical Epidemiology and Aging

Department of Health Research Methods, Evidence, and Impact

McMaster University

MIP 309A 1280 Main St. W.

Hamilton, ON, L8S 4K1

Email: acosta@mcmaster.ca

Word count: 2587

Figures: 1

Tables: 3

Appendices: 5

References: 33

Funding: This work was funded by the Juravinski Research Institute, in partnership with the St. Joseph's Healthcare Foundation, McMaster University and the Hamilton Health Sciences Foundation, Ontario, Canada.

Keywords: COVID-19, SARS-COV-2, coronavirus, outbreak, retirement home, assisted living, race and ethnicity 
medRxiv preprint doi: https://doi.org/10.1101/2020.12.08.20246124; this version posted December $11,2020$. The copyright holder for this preprint (which was not certified by peer review) is the author/funder, who has granted medRxiv a license to display the preprint in perpetuity.

It is made available under a CC-BY-NC-ND 4.0 International license .

\begin{abstract}
Background: The epidemiology of COVID-19 in retirement homes (also known as assisted living facilities) is largely unknown. We examined the association between retirement home and community level characteristics and the risk of COVID-19 outbreaks in retirement homes during the first wave of the COVID-19 epidemic.
\end{abstract}

Methods: We conducted a population-based retrospective cohort study of licensed retirement homes in Ontario, Canada, from March 1st - September 24th, 2020. Our primary outcome was a COVID-19 outbreak ( $\geq 1$ resident or staff confirmed case by validated nucleic acid amplification assay). We used time-dependent proportional hazards methods to model the associations between retirement home and community level characteristics and COVID-19 outbreaks. Results: Our cohort included all 770 licensed retirement homes in Ontario, which housed 56,491 residents. There were 172 (22.3\%) COVID-19 retirement home outbreaks involving $1,045(1.9 \%)$ residents and 548 staff (1.5\%). COVID-19 cases were distributed unevenly across retirement homes, with 1,593 (92.2\%) resident and staff cases occurring in $77(10 \%)$ of homes. The adjusted hazard of a COVID-19 outbreak in a retirement home was positively associated with homes that had a large resident capacity, homes that were co-located with a long-term care facility, large corporate owned chains, homes that offered many services onsite, increases in regional COVID-19 incidence, and a higher community-level ethnic concentration. Interpretation: Readily identifiable retirement home-level characteristics are independently associated with COVID-19 outbreaks and may support risk identification. A higher ethnic concentration of the community surrounding a retirement home is associated COVID-19 outbreaks, with an uncertain mechanism. 
medRxiv preprint doi: https://doi.org/10.1101/2020.12.08.20246124; this version posted December 11, 2020. The copyright holder for this preprint (which was not certified by peer review) is the author/funder, who has granted medRxiv a license to display the preprint in perpetuity.

It is made available under a CC-BY-NC-ND 4.0 International license .

\section{Introduction}

Frail older adults living in congregate care settings have been at the centre of the Coronavirus Disease 2019 (COVID-19) pandemic in Canada and internationally (1,2). Long-term care (LTC) facilities - the congregate living population most affected by COVID-19-have been the subject of immense scientific and public interest during the pandemic (3). Retirement homes (often known as assisted living facilities) have received far less examination despite also housing a large population of vulnerable older adults (4-7). Retirement homes are predominantly private residential complexes that provide a range of services (e.g., ADL assistance, meals, medication management) that are typically less-intensive compared to LTC facilities. They are almost exclusively financed through out-of-pocket payments by residents or their families (8), and the lack of consistent regulation throughout Canada and the United States has limited research into the epidemiology of COVID-19 in retirement homes (9).

There are close to 800 licensed retirement homes in Canada's most populous province of Ontario that house over 50,000 older adults, a population size that approaches the number of Ontario LTC home residents (10). Since the onset of the COVID-19 pandemic in Ontario, the number of positive cases and deaths in retirement homes continued to grow. As of November 16th, 2020, retirement home residents accounted for approximately $8 \%$ of COVID-19 deaths in Ontario (287/3505) (11). COVID-19 outbreaks have surged in retirement homes during the second wave in Canada and the United States $(11,12)$, with limited examination beyond early reports of case identification (13).

We examined the association between home and community level characteristics and the risk of COVID-19 outbreaks during the first wave of the COVID-19 epidemic in Ontario's 
medRxiv preprint doi: https://doi.org/10.1101/2020.12.08.20246124; this version posted December $11,2020$. The copyright holder for this preprint (which was not certified by peer review) is the author/funder, who has granted medRxiv a license to display the preprint in perpetuity.

It is made available under a CC-BY-NC-ND 4.0 International license .

retirement homes. Consistent with our previous population-level work in Ontario LTC homes $(2,14)$, we hypothesized that home size and regional COVID-19 incidence would be associated with the risk of an outbreak.

\section{Methods}

Study design

We conducted a retrospective cohort study across all retirement homes in Ontario, Canada from March 1st, 2020 until September $24^{\text {th }} 2020$; spanning the entirety of Ontario's first wave of the COVID-19 pandemic (15). In Ontario, retirement homes are defined in legislation (similar to other North American jurisdictions) as residential complexes that are occupied primarily by persons who are 65 years of age or older and have at least two of thirteen care services available (Appendix 1)(16,17). Our study was approved by the Hamilton Integrated Research Ethics Board. We adhered to the Strengthening the Reporting of Observational Studies in Epidemiology (STROBE) reporting guideline and the Reporting of Studies Conducted Using Observational Routinely-Collected Health Data (RECORD) statement guidelines (Appendix

2) $(18,19)$.

Data sources

Data used for this study were obtained from the Ontario Retirement Homes Regulatory Authority (RHRA) and Ontario Ministry of Health as part of the COVID-19 Ontario Consensus Modelling Table. We obtained home-level daily COVID-19 case counts and deaths among retirement home residents and staff (in home or hospital) from the RHRA through their COVID Tracking Tool. These data, which include the date on which a COVID-19 outbreak was declared 
medRxiv preprint doi: https://doi.org/10.1101/2020.12.08.20246124; this version posted December $11,2020$. The copyright holder for this preprint (which was not certified by peer review) is the author/funder, who has granted medRxiv a license to display the preprint in perpetuity.

It is made available under a CC-BY-NC-ND 4.0 International license .

and deemed resolved, were collected through daily direct inquires by the RHRA and through self-reports by licensed retirement homes to the RHRA and have recently been publicly reported (11). Licensed retirement homes are required to report COVID-19 outbreaks to the RHRA at the same time they are reported to their local public health units. Data from the tracking tool correlated closely with other provincial data sources including the integrated Public Health Information System, the Ontario Laboratory Information System, and a death database maintained by the Ontario Chief Coroner's office, and have been used in COVID-19 research in LTC homes $(2,14)$.

Exposures

We obtained home-level exposure data from the provincial registry of licensed retirement homes, which contains data on resident capacity, co-location with a LTC facility, and the availability of care services onsite for all retirement homes in Ontario. The RHRA is legislatively mandated to maintain the registry as the provincial retirement homes regulator. Home size was based on reported resident capacity and assigned to quintiles. Co-location of the retirement home with a LTC facility was identified by RHRA records as those homes sharing the same physical building or situated on the same site. Information on chain ownership was supplied by the RHRA, and homes were classified as being members of a small ( 2 to 5 homes), medium ( 6 to 20 homes) or large ( $>20$ homes) chain, or not part of a chain. The RHRA maintains a list of 13 services offered (Appendix 1) and a home's services were summed and assigned to the following categories: $\leq 6,7,8$, or $\geq 9$ services.

We obtained data on home level occupancy, staffing counts, and external care providers from an RHRA survey of all retirement homes conducted in May 2020 (home level response = 
medRxiv preprint doi: https://doi.org/10.1101/2020.12.08.20246124; this version posted December $11,2020$. The copyright holder for this preprint (which was not certified by peer review) is the author/funder, who has granted medRxiv a license to display the preprint in perpetuity.

It is made available under a CC-BY-NC-ND 4.0 International license .

92.7\%). External care providers come into the home either as contracted workers of the publicly funded home care program, or by private pay arrangement with residents. A staff to resident ratio comprising both types of external care providers was calculated based on the home survey response values and assigned to quartiles.

We obtained the daily incidence of COVID-19 across Ontario's 36 public health regions from Public Health Ontario's integrated Public Health Information System $(20,21)$. Time varying COVID-19 incidence was calculated each day as the rolling 14-day incidence per 1000 population for the public health unit in which the retirement home resided. We chose a rolling 14-day incidence based on the trend of community incidence rates (See Appendix 3 and 4). We conducted a sensitivity analysis using a 30-day time period, as well as by centering the index day in the rolling average period. We obtained linked data on community-level median household income and ethnic concentration from the Ontario Ministry of Health based on the 2016 Canadian Census and the Ontario Marginalization Index, respectively. We obtained the neighbourhood-level ethnic concentration surrounding each retirement home, which is defined as the combined proportions non-white and non-Indigenous residents and immigrants that arrived in Canada within the past five years, based on the 2016 Canadian Census $(22,23)$. The population size situating each retirement home was calculated using Statistics Canada's Postal Code Conversion File Plus (PCCF+), using postal codes from the Canada Post Corporation which were current up to and including November 2018; communities with a population size of $<10,000$ individuals are rural (24).

\section{Outcomes}


medRxiv preprint doi: https://doi.org/10.1101/2020.12.08.20246124; this version posted December 11, 2020. The copyright holder for this preprint (which was not certified by peer review) is the author/funder, who has granted medRxiv a license to display the preprint in perpetuity.

It is made available under a CC-BY-NC-ND 4.0 International license .

Our primary outcome was a COVID-19 outbreak ( $\geq 1$ resident or staff case confirmed by validated nucleic acid amplification assay)

\section{Statistical Analysis}

Summary statistics were computed to compare, by COVID-19 outbreak status, retirement home and community level characteristics. The Chi-square test was used for categorical variables and the Kruskal-Wallis test was used for continuous variables. Case fatality rates were calculated as the proportion of residents who died of COVID-19 compared to the total number of residents infected with COVID-19.

We used Cox proportional hazards to model the associations between retirement home and community level characteristics and the risk of a COVID-19 outbreak. Community incidence of COVID-19 was a time-varying covariate, with all other measures being fixed. A retirement home was at risk of experiencing an event on all days (March 1 to September 24, 2020), except for days in which the home was experiencing an outbreak. When an outbreak was over the home returned to being at risk for a future outbreak. To account for correlation between observations within public health units and multiple outbreaks within the same retirement homes, we applied a robust sandwich estimator for the covariance matrix. We built multivariable models using a manual, forward selection approach, with community size forced into the model given its strong association with risk of outbreak in previous work. Selection proceeded in ascending order of bivariate $p$-values, retaining only variables with a $p<0.05$ in the multivariable model. After the initial forward selection, all unselected variables were again tested individually in the model, and retained if $p<0.05$. Finally, two-way interactions among selected covariates were examined. We examined the proportionality of hazards assumption 
medRxiv preprint doi: https://doi.org/10.1101/2020.12.08.20246124; this version posted December 11, 2020. The copyright holder for this preprint (which was not certified by peer review) is the author/funder, who has granted medRxiv a license to display the preprint in perpetuity.

It is made available under a CC-BY-NC-ND 4.0 International license .

using Kaplan-Meier plots and time-varying covariates. Some explanatory variables represented as quintiles were collapsed to three-levels to comply with proportionality requirements.

\section{Results}

COVID-19 Cases and Deaths in Retirement Homes

The analysis included all 770 licensed retirement homes in Ontario as of March 1st 2020. Overall, 172 (22.3\%) retirement homes experienced one or more COVID-19 outbreaks as of September $24^{\text {th }} 2020$, with $154(20.0 \%)$ having one outbreak and $18(2.33 \%)$ having two outbreaks. COVID-19 outbreaks in this period involved 1,045 (1.9\%) infected residents and 548 infected staff (1.5\%) (Table 1). Over 90\% of outbreaks occurred before June 2020 (Appendix 3). Almost half of all outbreaks involved both staff and resident cases, with outbreaks involving staff cases being more common than those that involved resident cases. The crude cumulative incidence of COVID-19 among residents was 18.5 per thousand. In homes with a resident infection, the median number of residents infected was 2 (IQR: 1-13). COVID-19 infection was distributed unevenly across retirement homes: $1,593(92.2 \%)$ resident and staff cases occurred in $77(10 \%)$ of homes. There were $51(6.6 \%)$ retirement homes with outbreaks resulting in one or more resident deaths, accounting for a total of 215 resident COVID-19 deaths (3.8 per 1,000 residents in Ontario) and a case fatality rate of $20.5 \%$.

Retirement Home Characteristics by Outbreak Status

Retirement homes housed 56,491 residents with an average of approximately 73 residents and 48 staff per home and an overall occupancy rate of $74.2 \%$ (Table 2 ). The majority of retirement homes had a capacity of over 100 residents, had external care providers that entered the home daily, were corporate-owned chains, were located in communities with 
medRxiv preprint doi: https://doi.org/10.1101/2020.12.08.20246124; this version posted December $11,2020$. The copyright holder for this preprint (which was not certified by peer review) is the author/funder, who has granted medRxiv a license to display the preprint in perpetuity.

It is made available under a CC-BY-NC-ND 4.0 International license .

larger populations and lower ethnic concentration, and offered more than 6 services to their residents on-site. The minority of retirement homes were co-located with a LTC facility.

Compared to retirement homes without outbreaks, those that experienced one or more COVID-

19 outbreaks were more likely to have larger capacity, be part of a corporate-owned chain, have external care providers entering the home on a daily basis, have more services available to their residents onsite, and be located in larger communities with a higher ethnic concentration. Risk of a COVID-19 outbreak

Increases in regional COVID-19 incidence during the Wave 1 period were strongly associated with COVID-19 outbreaks in retirement homes, where a 1 case per 1,000 person increase in the previous 14 days was associated with a 5.83-fold increase in the hazard of an outbreak (Table 3). In addition to regional COVID-19 incidence, the adjusted hazard of a COVID19 outbreak was positively associated with homes that had a large resident capacity, large corporate owned chains, homes that were co-located with a LTC facility (adjusted hazard ratio [aHR], 1.84; 95\% confidence interval [Cl] 1.23-2.74), homes that offered many services onsite, and a higher community-level ethnic concentration. There was pattern of more COVID-19 outbreaks in retirement homes with a higher community-level ethnic concentration across public health regions (Figure 1).

\section{Interpretation}

In this study of all 770 retirement homes in Ontario, Canada, we found that the hazard of a COVID-19 outbreak was positively associated with increases in regional COVID-19 incidence, homes that had a large resident capacity, homes that were co-located with a LTC 
medRxiv preprint doi: https://doi.org/10.1101/2020.12.08.20246124; this version posted December 11, 2020. The copyright holder for this preprint (which was not certified by peer review) is the author/funder, who has granted medRxiv a license to display the preprint in perpetuity.

It is made available under a CC-BY-NC-ND 4.0 International license .

facility, large corporate owned chains, homes that offered many services onsite, and a higher community-level ethnic concentration. We identify risk factors for COVID-19 outbreaks in retirement homes that can inform risk identification at the provincial and regional level, as has been done for the LTC sector (25).

Consistent with LTC facilities $(26,27)$, our findings support that the incidence of COVID19 in a public health region, large chains, and the size of retirement homes are important risk factors for COVID-19 outbreaks. We found a strong association between retirement home outbreaks and the 14-day rolling incidence of COVID-19 in the surrounding public health region, which aligns with the temporal relationship between community COVID-19 incidence and LTC outbreaks (28). Also consistent with the literature on COVID-19 and LTC $(2,14)$, we found that home capacity was associated with risk of COVID-19 outbreaks such that retirement homes with a capacity greater than 100 residents had more than a 5 -fold increase in risk of outbreak. Larger homes require more staff, which likely increases the number of potential individuals who are unknowingly importing COVID-19 into homes. Given that the majority of COVID-19 cases were accumulated early in Wave 1 during the period when visitors to retirement homes were severely restricted (Appendix 3), it is probable that retirement home staff and care providers were the main vectors for seeding COVID-19 infection into retirement homes (29). The lack of an adjusted association between the external care providers and COVID-19 outbreak might be explained by the lack of variability between retirement homes of the same size. Homes that offered 9 or more services had an almost 2-fold increase in risk for a COVID-19 outbreak. This likely reflects the additional exposure to SARS-COV-2 associated with additional and more lengthy interactions between staff and residents who require such services. 
medRxiv preprint doi: https://doi.org/10.1101/2020.12.08.20246124; this version posted December 11, 2020. The copyright holder for this preprint (which was not certified by peer review) is the author/funder, who has granted medRxiv a license to display the preprint in perpetuity.

It is made available under a CC-BY-NC-ND 4.0 International license .

Retirement homes that are co-located with a LTC facility had an almost 2-fold increase in risk for a COVID-19 outbreak. This finding could reflect staff working between homes, which has been linked to the transmission of COVID-19 between LTC facilities (25,30). Despite provincial orders restricting work at multiple healthcare settings within a 14-day period, emerging evidence suggests that residual connectivity between congregate living settings exists and could represent temporary agency workers and contract staff which are exempted from the provincial order (31). A reduction in mobility of staff between retirement and LTC homes may reduce the risk of COVID-19 outbreaks in co-located retirement homes during successive waves of the COVID-19 pandemic.

We observed an association between levels of ethnic concentration in the community surrounding a retirement home and the risk of COVID-19 outbreak, even after adjusting for regional COVID-19 rates and community level household income. Public Health Ontario reports demonstrate that ethno-culturally dense neighbourhoods experience disproportionately higher rates of COVID-19 (32). LTC facilities that care for more racial and ethnic minority residents report higher COVID-19 cases and/or deaths (33). Our finding may relate, at least partly, to cultural patterns of care and connection for older family members. However, we could not examine the complex relationship between COVID-19 and ethno-cultural characteristics in our analyses, and further data collection and analysis are needed to understand this mechanism.

Comparable to many emerging and rapidly collected sources of COVID-19 data, we could not independently validate completeness with respect to COVID-19 infections and deaths at the home level. We also could not account for temporal changes in infection prevention and control practices and changing provincial policies that may have influenced these results. Our 
medRxiv preprint doi: https://doi.org/10.1101/2020.12.08.20246124; this version posted December 11, 2020. The copyright holder for this preprint (which was not certified by peer review) is the author/funder, who has granted medRxiv a license to display the preprint in perpetuity.

It is made available under a CC-BY-NC-ND 4.0 International license .

study was limited by the lack of individual level data on clinical, organizational, and sociocultural characteristics that may differ across homes. A better understanding of the complex relationships between COVID-19 and ethno-cultural characteristics require further data at the individual level. Our adjustment of regional COVID-19 incidence may have caused over-adjustment given that some community cases may have been secondary to retirement home cases.

In conclusion, we find that the risk of a COVID-19 outbreak in retirement homes is associated with larger resident capacity, co-location with a LTC facility, large corporate owned chains, a higher availability of services onsite, and increases in regional COVID-19 incidence. For retirement homes co-located with a LTC facility, a reduction in staff mobility between settings is a potentially modifiable factor that may reduce the risk of future COVID-19 outbreaks.

Increased ethnic concentration of the community surrounding a retirement home is associated COVID-19 outbreaks, with an uncertain mechanism. Identifying and understanding observed differences in COVID-19 outbreaks across retirement homes may inform risk identification and prevention. 
medRxiv preprint doi: https://doi.org/10.1101/2020.12.08.20246124; this version posted December 11, 2020. The copyright holder for this preprint (which was not certified by peer review) is the author/funder, who has granted medRxiv a license to display the preprint in perpetuity. It is made available under a CC-BY-NC-ND 4.0 International license.

\section{Acknowledgements}

We gratefully acknowledge the support of Dr. Kamil Malikov of the Ontario Ministry of Health's Capacity Planning and Analytics Division for assistance with data acquisition. Andrew P. Costa holds the Schlegel Chair in Clinical Epidemiology and Aging at McMaster University. Nathan M.

Stall is supported by the Department of Medicine's Eliot Phillipson Clinician-Scientist Training Program and the Clinician Investigator Program at the University of Toronto, and the Vanier Canada Graduate Scholarship. 
medRxiv preprint doi: https://doi.org/10.1101/2020.12.08.20246124; this version posted December 11, 2020. The copyright holder for this preprint (which was not certified by peer review) is the author/funder, who has granted medRxiv a license to display the preprint in perpetuity.

It is made available under a CC-BY-NC-ND 4.0 International license .

\section{References}

1. CDC. Coronavirus Disease 2019 (COVID-19) [Internet]. Centers for Disease Control and Prevention. 2020 [cited 2020 Nov 24]. Available from: https://www.cdc.gov/coronavirus/2019-ncov/hcp/long-term-care.html

2. Brown KA, Jones A, Daneman N, Chan AK, Schwartz KL, Garber GE, et al. Association Between Nursing Home Crowding and COVID-19 Infection and Mortality in Ontario, Canada. JAMA Intern Med. 2020 Nov 9;

3. Hsu AT, Lane N. Impact of COVID-19 on residents of Canada's long-term care homes ongoing challenges and policy response. International Long Term Care Policy Network. 2020 Apr 22;15.

4. Zimmerman S, Sloane PD, Katz PR, Kunze M, O'Neil K, Resnick B. The Need to Include Assisted Living in Responding to the COVID-19 Pandemic. J Am Med Dir Assoc. 2020 May;21(5):572-5.

5. Poss JW, Sinn C-L, Grinchenko G, Blums J, Peirce T, Hirdes J. Location, Location, Location: Characteristics and Services of Long-Stay Home Care Recipients in Retirement Homes Compared to Others in Private Homes and Long-Term Care Homes. Healthc Policy. 2017;12(3):80-93.

6. Ducharme J. America's Assisted Living Residents Are "Falling Through the Cracks" of COVID19 Response. Time [Internet]. 2020 May 28 [cited 2020 Nov 24]; Available from: https://time.com/5843260/assisted-living-facilities-covid-19/

7. American Health Care Association. Facts \& Figures - Assisted Living [Internet]. 2020 [cited 2020 Nov 24]. Available from: https://www.ahcancal.org/Assisted-Living/Facts-andFigures/Pages/default.aspx

8. Roblin B, Deber R, Kuluski K, Silver MP. Ontario's Retirement Homes and Long-Term Care Homes: A Comparison of Care Services and Funding Regimes. Can J Aging. 2019 Jun;38(2):155-67.

9. True S, Ochieng N, Chidambaram P, 2020. Overlooked and Undercounted: The Growing Impact of COVID-19 on Assisted Living Facilities [Internet]. KFF. 2020 [cited 2020 Nov 9]. Available from: https://www.kff.org/coronavirus-covid-19/issue-brief/overlooked-andundercounted-the-growing-impact-of-covid-19-on-assisted-living-facilities/

10. Retirement Homes Regulatory Authority. Annual Report 2019/2020 [Internet]. 2020 [cited 2020 Nov 9] p. 47. Available from: https://www.rhra.ca/wpcontent/uploads/2020/09/20192020-RHRA-Annual-Report-FINAL.pdf

11. Retirement Homes Regulatory Authority. COVID-19 Dashboard [Internet]. 2020 [cited 2020 Nov 9]. Available from: https://www.rhra.ca/en/covid19dashboard/ 
medRxiv preprint doi: https://doi.org/10.1101/2020.12.08.20246124; this version posted December 11, 2020. The copyright holder for this preprint (which was not certified by peer review) is the author/funder, who has granted medRxiv a license to display the preprint in perpetuity.

It is made available under a CC-BY-NC-ND 4.0 International license .

12. Yi SH, See I, Kent AG, et al. Characterization of COVID-19 in Assisted Living Facilities - 39 States, October 2020. MMWR Morb Mortal Wkly Rep 2020;69:1730-1735. DOI: http://dx.doi.org/10.15585/mmwr.mm6946a3

13. Roxby AC, Greninger AL, Hatfield KM, Lynch JB, Dellit TH, James A, et al. Outbreak Investigation of COVID-19 Among Residents and Staff of an Independent and Assisted Living Community for Older Adults in Seattle, Washington. JAMA Intern Med [Internet]. 2020 May 21 [cited 2020 Nov 24]; Available from: https://www.ncbi.nlm.nih.gov/pmc/articles/PMC7292007/

14. Stall NM, Jones A, Brown KA, Rochon PA, Costa AP. For-profit long-term care homes and the risk of COVID-19 outbreaks and resident deaths. CMAJ [Internet]. 2020 Jan 1 [cited 2020 Jul 29]; Available from: https://www.cmaj.ca/content/early/2020/07/22/cmaj.201197.1

15. Government of Ontario. Ontario Releases Updated COVID-19 Modelling for Second Wave [Internet]. 2020 [cited 2020 Nov 24]. Available from: https://news.ontario.ca/en/release/58602/ontario-releases-updated-covid-19-modellingfor-second-wave

16. Retirement Homes Act, 2010 [Internet]. S.O. 2010, c. 11 Jun 8, 2010. Available from: https://www.ontario.ca/laws/statute/10r11\#BK13

17. Retirement Homes Regulatory Authority. Understanding the Act [Internet]. 2020 [cited 2020 Nov 9]. Available from: https://www.rhra.ca/en/about-rhra/our-role/understandingthe-act/

18. von Elm E, Altman DG, Egger M, Pocock SJ, Gøtzsche PC, Vandenbroucke JP, et al. The Strengthening the Reporting of Observational Studies in Epidemiology (STROBE) statement: guidelines for reporting observational studies. Epidemiology. 2007 Nov;18(6):800-4.

19. Benchimol El, Smeeth L, Guttmann A, Harron K, Moher D, Petersen I, et al. The REporting of studies Conducted using Observational Routinely-collected health Data (RECORD) Statement. PLOS Medicine. 2015 Oct 6;12(10):e1001885.

20. Public Health Ontario. iPHIS Resources [Internet]. Public Health Ontario. 2020 [cited 2020 Nov 9]. Available from: https://www.publichealthontario.ca/Diseases and Conditions/Infectious Diseases/CCM/iPHIS

21. Government of Ontario. Confirmed positive cases of COVID19 in Ontario [Internet]. Government of Ontario; 2020 [cited 2020 Sep 30]. Available from: https://data.ontario.ca/dataset/f4112442-bdc8-45d2-be3c12efae72fb27/resource/455fd63b-603d-4608-8216$7 \mathrm{~d} 8647 \mathrm{f} 43350 /$ download/conposcovidloc.csv 
medRxiv preprint doi: https://doi.org/10.1101/2020.12.08.20246124; this version posted December 11, 2020. The copyright holder for this preprint (which was not certified by peer review) is the author/funder, who has granted medRxiv a license to display the preprint in perpetuity.

It is made available under a CC-BY-NC-ND 4.0 International license .

22. Matheson FI, Dunn JR, Smith KLW, Moineddin R, Glazier RH. Development of the Canadian Marginalization Index: a new tool for the study of inequality. Can J Public Health. $2012 \mathrm{Apr}$ 30;103(8 Suppl 2):S12-16.

23. Public Health Ontario. Ontario Marginalization Index (ON-Marg) [Internet]. Public Health Ontario. 2020 [cited 2020 Nov 9]. Available from: https://www.publichealthontario.ca/Data and Analysis/Health Equity/Ontario Marginalization Index

24. Government of Canada SC. Postal Code OM Conversion File Plus (PCCF+) [Internet]. 2017 [cited 2020 Nov 24]. Available from: https://www150.statcan.gc.ca/n1/en/catalogue/82F0086X

25. Capacity Panning and Analytics Overview. Ontario's Long-Term Care COVID-19 Commission [Internet]. 2020 [cited 2020 Nov 9] p. 23. http://Itccommissioncommissionsld.ca/cm/pdf/LTCC_Capacity_Planning_and_Analytics_Overview.pdf

26. McMichael TM, Currie DW, Clark S, Pogosjans S, Kay M, Schwartz NG, et al. Epidemiology of Covid-19 in a Long-Term Care Facility in King County, Washington. N Engl J Med. 2020 21;382(21):2005-11.

27. Fisman DN, Bogoch I, Lapointe-Shaw L, McCready J, Tuite AR. Risk Factors Associated With Mortality Among Residents With Coronavirus Disease 2019 (COVID-19) in Long-term Care Facilities in Ontario, Canada. JAMA Netw Open [Internet]. 2020 Jul 22 [cited 2020 Nov 24];3(7). Available from: https://www.ncbi.nlm.nih.gov/pmc/articles/PMC7376390/

28. Malikov K, Huang Q, Shi S, Stall NM, Tuite AR, Hillmer MP. Temporal Associations between Community Incidence of COVID-19 and Nursing Home Outbreaks in Ontario, Canada. medRxiv. 2020 Nov 19;2020.11.17.20233312.

29. Chow EJ, Schwartz NG, Tobolowsky FA, Zacks RLT, Huntington-Frazier M, Reddy SC, et al. Symptom Screening at Illness Onset of Health Care Personnel With SARS-CoV-2 Infection in King County, Washington. JAMA. 2020 26;323(20):2087-9.

30. Van Houtven CH, DePasquale N, Coe NB. Essential Long-Term Care Workers Commonly Hold Second Jobs and Double- or Triple-Duty Caregiving Roles. J Am Geriatr Soc. 2020;68(8):1657-60.

31. Jones A, Watts AG, Khan SU, Forsyth J, Brown KA, Costa AP, et al. Impact of a public policy restricting staff mobility between long-term care homes in Ontario, Canada during the COVID-19 pandemic. medRxiv. 2020 Nov 18;2020.11.17.20231498.

32. Public Health Ontario. Enhanced Epidemiological Summary: COVID-19 in Ontario - A Focus on Diversity [Internet]. 2020 [cited 2020 Nov 9]. Available from: https://www.publichealthontario.ca/-/media/documents/ncov/epi/2020/06/covid-19-epidiversity.pdf?la=en 
medRxiv preprint doi: https://doi.org/10.1101/2020.12.08.20246124; this version posted December 11, 2020. The copyright holder for this preprint (which was not certified by peer review) is the author/funder, who has granted medRxiv a license to display the preprint in perpetuity.

It is made available under a CC-BY-NC-ND 4.0 International license .

33. Li Y, Cen X, Cai X, Temkin-Greener H. Racial and Ethnic Disparities in COVID-19 Infections and Deaths Across U.S. Nursing Homes. J Am Geriatr Soc. 2020 Sep 21.

Table 1: COVID-19 outbreaks and deaths in Retirement Homes, Ontario (Mar. 1-Sep. 24, 2020; $\mathrm{N}=770$ )

\begin{tabular}{|c|c|}
\hline & $\begin{array}{l}\text { All licensed } \\
\text { retirement homes } \\
(n=770)\end{array}$ \\
\hline \multicolumn{2}{|l|}{ COVID-19 Outbreaks N (\% facilities) } \\
\hline $1+$ Outbreaks & $172(22.3 \%)$ \\
\hline Outbreaks involving both residents and staff & $78(10.1 \%)$ \\
\hline Outbreaks involving residents only & $39(5.1 \%)$ \\
\hline Outbreaks involving staff only & $55(7.1 \%)$ \\
\hline \multicolumn{2}{|l|}{ COVID-19 Cases } \\
\hline Staff Infections, $\mathrm{N}$ & 548 \\
\hline Resident Infections, N & 1,045 \\
\hline $\begin{array}{r}\text { Cumulative incidence of COVID-19 resident } \\
\text { cases (per thousand RH residents) }\end{array}$ & 18.5 \\
\hline $\begin{array}{l}\text { Proportion of residents infected per home } \\
\text { with a resident infection, median (IQR) }\end{array}$ & $\begin{array}{c}3.0 \% \\
(1.3 \%-13.6 \%)\end{array}$ \\
\hline $\begin{array}{r}\text { Median number of cases per home with a } \\
\text { resident infection, (IQR) }\end{array}$ & $\begin{array}{c}2 \\
(1-13) \\
\end{array}$ \\
\hline \multicolumn{2}{|l|}{ COVID-19 Deaths } \\
\hline Homes with $1+$ COVID-19 deaths $\mathrm{N}$ & 51 \\
\hline COVID-19 deaths $\mathrm{N}$ & 215 \\
\hline $\begin{array}{r}\text { COVID-19 death rate (per thousand } \mathrm{RH} \\
\text { residents) }\end{array}$ & 3.81 \\
\hline $\begin{array}{r}\text { Proportion of residents who died per home } \\
\text { with a resident death, median (IQR) }\end{array}$ & $\begin{array}{c}4.2 \% \\
(1.4 \%-8.2 \%)\end{array}$ \\
\hline $\begin{array}{r}\text { Median number of deaths per home with } \\
\text { one or more deaths (IQR) }\end{array}$ & $\begin{array}{c}3 \\
(1-6)\end{array}$ \\
\hline Case fatality rate $\%$ & $20.5 \%$ \\
\hline
\end{tabular}


medRxiv preprint doi: https://doi.org/10.1101/2020.12.08.20246124; this version posted December 11, 2020. The copyright holder for this preprint (which was not certified by peer review) is the author/funder, who has granted medRxiv a license to display the preprint in perpetuity.

It is made available under a CC-BY-NC-ND 4.0 International license .

Table 2: Characteristics of retirement homes by COVID-19 outbreak status, Ontario (Mar. 1Sep. 24, 2020; $N=770$ )

\begin{tabular}{|c|c|c|c|c|}
\hline \multirow[t]{2}{*}{ Measures } & \multirow[t]{2}{*}{ All Facilities } & \multicolumn{3}{|c|}{$\begin{array}{c}\text { COVID-19 Outbreak } \\
\text { (as of September } 24^{\text {th }} 2020 \text { ) }\end{array}$} \\
\hline & & $\geq 1$ Outbreaks & 0 Outbreaks & $p$-value ${ }^{2}$ \\
\hline Homes N (\%) & $770(100 \%)$ & $172(22.3 \%)$ & $598(77.7 \%)$ & \\
\hline Number of residents* N (\%) & 56,491 & $16,698(29.6 \%)$ & $39,793(70.4 \%)$ & \\
\hline $\begin{array}{l}\text { Number of residents per } \\
\text { home* (mean) }\end{array}$ & 73.4 & 97.1 & 66.5 & $<.0001$ \\
\hline $\begin{array}{l}\text { Number of total staff per } \\
\text { home* (mean) }\end{array}$ & 48.1 & 67.5 & 42.7 & $<.0001$ \\
\hline \multicolumn{5}{|l|}{ Home Characteristics } \\
\hline \multicolumn{5}{|l|}{$\begin{array}{l}\text { Total Resident Capacity N } \\
(\%)\end{array}$} \\
\hline$<45$ & $149(19.4 \%)$ & $10(5.8 \%)$ & $139(23.2 \%)$ & \multirow{5}{*}{$<.0001$} \\
\hline $45-74$ & $151(19.6 \%)$ & $19(11.1 \%)$ & $132(22.1 \%)$ & \\
\hline $75-109$ & $148(19.2 \%)$ & $37(21.5 \%)$ & $111(18.6 \%)$ & \\
\hline 110 to 151 & $167(21.7 \%)$ & $51(29.7 \%)$ & $116(19.4 \%)$ & \\
\hline $152+$ & $155(20.1 \%)$ & $55(32.0 \%)$ & $100(16.7 \%)$ & \\
\hline Occupancy Rate* (mean) & $74.2 \%$ & $71.9 \%$ & $74.9 \%$ & 0.216 \\
\hline Number of Suites (mean) & 84.3 & 114.4 & 75.6 & $<.0001$ \\
\hline $\begin{array}{l}\text { Co-located with a LTC } \\
\text { facility N (\%) }\end{array}$ & $101(13.1 \%)$ & $26(15.1 \%)$ & $75(12.5 \%)$ & 0.378 \\
\hline \multicolumn{5}{|l|}{$\begin{array}{l}\text { Number of External care } \\
\text { providers that enter home } \\
\text { daily* (mean) }\end{array}$} \\
\hline 0 & $113(14.7 \%)$ & $15(8.7 \%)$ & $98(16.4 \%)$ & \multirow{6}{*}{0.031} \\
\hline $1+$, exact number unknown & $86(11.2 \%)$ & $22(12.8 \%)$ & $64(10.7 \%)$ & \\
\hline 1 or 2 & $172(22.3 \%)$ & $36(20.9 \%)$ & $136(22.7 \%)$ & \\
\hline 3 to 6 & $247(32.1 \%)$ & $60(34.9 \%)$ & $187(31.3 \%)$ & \\
\hline $7+$ & $96(12.5 \%)$ & $30(17.4 \%)$ & $66(11.0 \%)$ & \\
\hline missing & $56(7.3 \%)$ & $9(5.2 \%)$ & 47 (7.9\%) & \\
\hline
\end{tabular}

Active staff to resident ratio* $\mathrm{N}(\%)$

\begin{tabular}{|c|c|c|c|c|}
\hline Less than 0.49 & $178(23.1 \%)$ & $36(20.9 \%)$ & $142(23.8 \%)$ & \multirow{5}{*}{0.110} \\
\hline 0.49 to 0.64 & $186(24.2 \%)$ & $34(19.8 \%)$ & $152(25.4 \%)$ & \\
\hline 0.64 to 0.84 & $175(22.7 \%)$ & $44(25.6 \%)$ & $131(21.9 \%)$ & \\
\hline Greater than 0.84 & $166(21.6 \%)$ & $47(27.3 \%)$ & $119(19.9 \%)$ & \\
\hline Missing & $65(8.4 \%)$ & $11(6.4 \%)$ & $54(9.0 \%)$ & \\
\hline
\end{tabular}


medRxiv preprint doi: https://doi.org/10.1101/2020.12.08.20246124; this version posted December 11, 2020. The copyright holder for this preprint (which was not certified by peer review) is the author/funder, who has granted medRxiv a license to display the preprint in perpetuity.

It is made available under a CC-BY-NC-ND 4.0 International license .

\begin{tabular}{|c|c|c|c|c|}
\hline \multicolumn{5}{|l|}{ chain N (\%) } \\
\hline Not a chain & $305(39.6 \%)$ & $49(28.5 \%)$ & $256(42.8 \%)$ & \multirow{4}{*}{$<.0001$} \\
\hline small (2 to 5) & $87(11.3 \%)$ & $12(7.0 \%)$ & $75(12.5 \%)$ & \\
\hline medium (6 to 20 ) & $174(22.6 \%)$ & $45(26.2 \%)$ & $129(21.6 \%)$ & \\
\hline large $(>20)$ & $204(26.5 \%)$ & $66(38.4 \%)$ & $138(23.1 \%)$ & \\
\hline \multicolumn{5}{|l|}{$\begin{array}{l}\text { Number of available } \\
\text { services } N(\%)\end{array}$} \\
\hline 6 or fewer & $165(21.4 \%)$ & $21(12.2 \%)$ & $144(24.1 \%)$ & \multirow{4}{*}{$<.0001$} \\
\hline 7 & $275(35.7 \%)$ & $59(34.3 \%)$ & $216(36.1 \%)$ & \\
\hline 8 & $176(22.9 \%)$ & $40(23.3 \%)$ & $136(22.7 \%)$ & \\
\hline $9+$ & $154(20.0 \%)$ & $52(30.2 \%)$ & $102(17.1 \%)$ & \\
\hline \multicolumn{5}{|l|}{ Community Characteristics } \\
\hline \multicolumn{5}{|l|}{$\begin{array}{l}\text { Regional COVID-19 } \\
\text { incidence (per 1,000 }\end{array}$} \\
\hline residents)^ $\mathbf{N}(\%)$ & & & & \\
\hline 1st Quintile $(0.288,1.332)$ & $133(17.3 \%)$ & $11(6.4 \%)$ & $122(20.4 \%)$ & \multirow{4}{*}{$<.0001$} \\
\hline 2nd Quintile $(1.333,2.136)$ & $157(20.4 \%)$ & $17(9.9 \%)$ & $149(23.4 \%)$ & \\
\hline 3rd Quintile $(2.137,3.231)$ & $149(19.4 \%)$ & $26(15.1 \%)$ & $123(20.6 \%)$ & \\
\hline 4th Quintile $(3.232,4.589)$ & $192(24.9 \%)$ & $62(36.1 \%)$ & $130(21.7 \%)$ & \\
\hline 5th Quintile $(4.590,6.757)$ & $139(18.1 \%)$ & $56(32.6 \%)$ & $83(13.9 \%)$ & \\
\hline \multicolumn{5}{|l|}{$\begin{array}{l}\text { Community population size } \\
N(\%)\end{array}$} \\
\hline $500,000+$ & $349(45.3 \%)$ & $111(64.5 \%)$ & $238(39.8 \%)$ & \multirow{3}{*}{$<.0001$} \\
\hline $10,000-499,999$ & $295(38.3 \%)$ & $48(27.9 \%)$ & $247(41.3 \%)$ & \\
\hline$<10,000$ & $126(16.4 \%)$ & $13(7.6 \%)$ & $113(18.9 \%)$ & \\
\hline \multicolumn{5}{|l|}{$\begin{array}{l}\text { Median household income } \\
\mathrm{N}(\%)\end{array}$} \\
\hline $\begin{array}{r}\text { 1st quintile }(14,777- \\
51,925)\end{array}$ & $181(23.5 \%)$ & $46(26.7 \%)$ & $135(22.6 \%)$ & \multirow{5}{*}{0.199} \\
\hline $\begin{array}{r}\text { 2nd quintile }(52,267- \\
68,032)\end{array}$ & $183(23.8 \%)$ & $45(26.2 \%)$ & $138(23.1 \%)$ & \\
\hline $\begin{array}{r}\text { 3rd quintile }(68,352- \\
84,160)\end{array}$ & $162(21.0 \%)$ & $31(18.0 \%)$ & $131(21.9 \%)$ & \\
\hline $\begin{array}{r}\text { 4th quintile }(84,352- \\
103,424)\end{array}$ & $149(19.4 \%)$ & $25(14.5 \%)$ & $124(20.7 \%)$ & \\
\hline $\begin{array}{r}\text { 5th quintile }\left(\begin{array}{r}103,834- \\
251,008)\end{array}\right.\end{array}$ & $95(12.3 \%)$ & 25 (14.5\%) & 70 (11.7\%) & \\
\hline \multicolumn{5}{|l|}{ Ethnic concentration ${ }^{2} \mathrm{~N}(\%)$} \\
\hline $\begin{array}{r}\text { 1st quintile (least } \\
\text { concentrated) }\end{array}$ & $167(21.7 \%)$ & $15(8.9 \%)$ & $152(25.4 \%)$ & \multirow{3}{*}{$<.0001$} \\
\hline 2nd quintile & $200(26.0 \%)$ & $25(15.2 \%)$ & 175 (29.3\%) & \\
\hline 3rd quintile & $166(21.6 \%)$ & $40(20.9 \%)$ & $126(21.1 \%)$ & \\
\hline
\end{tabular}


medRxiv preprint doi: https://doi.org/10.1101/2020.12.08.20246124; this version posted December 11, 2020. The copyright holder for this preprint (which was not certified by peer review) is the author/funder, who has granted medRxiv a license to display the preprint in perpetuity.

It is made available under a CC-BY-NC-ND 4.0 International license .

\begin{tabular}{rlll}
\hline 4th quintile & $145(18.8 \%)$ & $61(35.1 \%)$ & $84(14.1 \%)$ \\
\hline $\begin{array}{r}\text { 5th quintile (most } \\
\text { concentrated) }\end{array}$ & $92(12.0 \%)$ & $31(19.9 \%)$ & $61(10.2 \%)$ \\
\hline
\end{tabular}

${ }^{1}$ Defined as $\geq 1$ COVID-19 cases among resident or staff

${ }^{2}$ Defined by the Ontario Marginalization Index as the proportion of non-white and non-Indigenous residents and the proportion of immigrants that arrived in Canada within the past five years.

*As of May 2020

^ March $1^{\text {st }}$ to September $24^{\text {th }}$. Quintiles are based on the June 1,2020 , distribution. 
medRxiv preprint doi: https://doi.org/10.1101/2020.12.08.20246124; this version posted December 11, 2020. The copyright holder for this preprint (which was not certified by peer review) is the author/funder, who has granted medRxiv a license to display the preprint in perpetuity.

It is made available under a CC-BY-NC-ND 4.0 International license .

Table 3. Associations between home and regional characteristics with time to COVID-19 resident outbreak, cumulative COVID-19 cases count, and COVID-19 resident deaths, Ontario, Mar 1-Sep. 242020 ( $N=770$ facilities)

\begin{tabular}{|c|c|c|}
\hline & \multicolumn{2}{|c|}{$\begin{array}{c}\text { COVID-19 Outbreak }{ }^{1} \\
\left.\text { (as of September } 24^{\text {th }} 2020\right) \text { HR }(95 \% \mathrm{Cl})\end{array}$} \\
\hline & Hazard ratio (HR) & $\begin{array}{l}\text { Adjusted hazard } \\
\text { ratio (aHR) }\end{array}$ \\
\hline \multicolumn{3}{|l|}{ Regional COVID-19 incidence } \\
\hline $\begin{array}{l}\text { Time varying incidence in past } 14 \text { days, } \\
\text { increase in } 1 \text { case per } 1,000\end{array}$ & $8.76(5.60-13.72)$ & $5.83(3.19-10.64)$ \\
\hline \multicolumn{3}{|l|}{ Home-level Characteristics } \\
\hline \multicolumn{3}{|l|}{ Total resident capacity } \\
\hline$<45$ & Reference & Reference \\
\hline $45-74$ & $2.28(1.07-4.85)$ & $2.49(1.16-5.36)$ \\
\hline $75-109$ & $4.19(2.12-8.28)$ & $3.74(1.80-7.75)$ \\
\hline 110 to 151 & $5.23(2.71-10.09)$ & $5.16(2.48-10.76)$ \\
\hline $152+$ & $5.98(3.11-11.48)$ & $4.50(2.14-9.43)$ \\
\hline Co-located with LTC facility & $1.36(0.91-2.02)$ & $1.82(1.22-2.73)$ \\
\hline \multicolumn{3}{|l|}{$\begin{array}{l}\text { Number of external care providers that } \\
\text { enter facility daily }\end{array}$} \\
\hline 0 & reference & Reference \\
\hline 1+, exact number unknown & $1.95(1.04-3.65)$ & $0.65(0.33-1.26)$ \\
\hline 1 or 2 & $1.52(0.85-2.73)$ & $1.02(0.57-1.85)$ \\
\hline 3 to 6 & $1.96(1.13-3.41)$ & $0.89(0.50-1.58)$ \\
\hline $7+$ & $2.67(1.47-4.87)$ & $0.85(0.46-1.59)$ \\
\hline Missing & $1.28(0.56-2.89)$ & $1.29(0.60-2.75)$ \\
\hline \multicolumn{3}{|l|}{ Staff to resident ratio } \\
\hline Less than 0.49 & Reference & \\
\hline 0.49 to 0.64 & $0.83(0.53-1.30)$ & \\
\hline 0.64 to 0.84 & $1.21(0.80-1.84)$ & \\
\hline Greater than 0.84 & $1.45(0.95-2.19)$ & \\
\hline Missing & $0.82(0.42-1.58)$ & \\
\hline \multicolumn{3}{|l|}{ Size of corporate-owned chain } \\
\hline Not a chain & Reference & Reference \\
\hline small (2 to 5 ) & $0.81(0.44-1.48)$ & $0.76(0.41-1.39)$ \\
\hline medium (6 to 20 ) & $1.72(1.17-2.54)$ & $1.33(0.88-2.01)$ \\
\hline chain large $(>20)$ & $2.16(1.53-3.07)$ & $1.58(1.02-2.44)$ \\
\hline \multicolumn{3}{|l|}{ Number of RH services available * } \\
\hline 6 or fewer & Reference & Reference \\
\hline 7 & $1.72(1.07-2.76)$ & $1.09(0.66-1.83)$ \\
\hline 8 & $2.01(1.21-3.35)$ & $1.47(0.88-2.46)$ \\
\hline $9+$ & $3.17(1.96-5.12)$ & $1.83(1.15-2.93)$ \\
\hline
\end{tabular}


medRxiv preprint doi: https://doi.org/10.1101/2020.12.08.20246124; this version posted December 11, 2020. The copyright holder for this preprint (which was not certified by peer review) is the author/funder, who has granted medRxiv a license to display the preprint in perpetuity.

It is made available under a CC-BY-NC-ND 4.0 International license .

\begin{tabular}{|c|c|c|}
\hline & \multicolumn{2}{|c|}{$\begin{array}{c}\text { COVID-19 Outbreak }^{1} \\
\left.\text { (as of September } 24^{\text {th }} 2020\right) \text { HR }(95 \% \mathrm{Cl})\end{array}$} \\
\hline \multicolumn{3}{|l|}{ Community-level Characteristics } \\
\hline \multicolumn{3}{|l|}{ Population size } \\
\hline $500,000+$ & $3.24(1.83-5.72)$ & $0.73(0.38-1.40)$ \\
\hline $10,000-499,999$ & $1.63(0.89-3.01)$ & $0.82(0.44-1.51)$ \\
\hline$<10,000$ & Reference & Reference \\
\hline \multicolumn{3}{|l|}{ Median household income } \\
\hline $1^{\text {st }}, 2^{\text {nd }}$ quintiles $(14,777-68,032)$ & Reference & Reference \\
\hline $3^{\text {rd }}$ quintile $(68,352-84,160)$ & $0.85(0.57-1.25)$ & $0.88(0.61-1.26)$ \\
\hline 4th, 5 th quintiles $(84,352-251,008)$ & $0.86(0.62-1.19)$ & $0.71(0.51-0.98)$ \\
\hline \multicolumn{3}{|l|}{ Ethnic concentration $^{2}$} \\
\hline $1^{\text {st }}, 2^{\text {nd }}$ quintiles (less concentrated) & Reference & Reference \\
\hline 3rd quintile & $2.22(1.45-3.39)$ & $1.68(1.05-2.69)$ \\
\hline $4^{\text {th }}, 5^{\text {th }}$ quintiles (more concentrated) & $3.75(2.62-5.37)$ & $2.12(1.34-3.37)$ \\
\hline
\end{tabular}

${ }^{1}$ Defined as $\geq 1$ COVID-19 cases among resident or staff

${ }^{2}$ Defined by the Ontario Marginalization Index as the proportion of non-white and non-Indigenous residents and the proportion of immigrants that arrived in Canada within the past five years.

* Including: bathing, hygiene, ambulation, feeding, wound care, continence care, medication administration, meals, dementia care, dressing, pharmacy, medical, and nursing. 


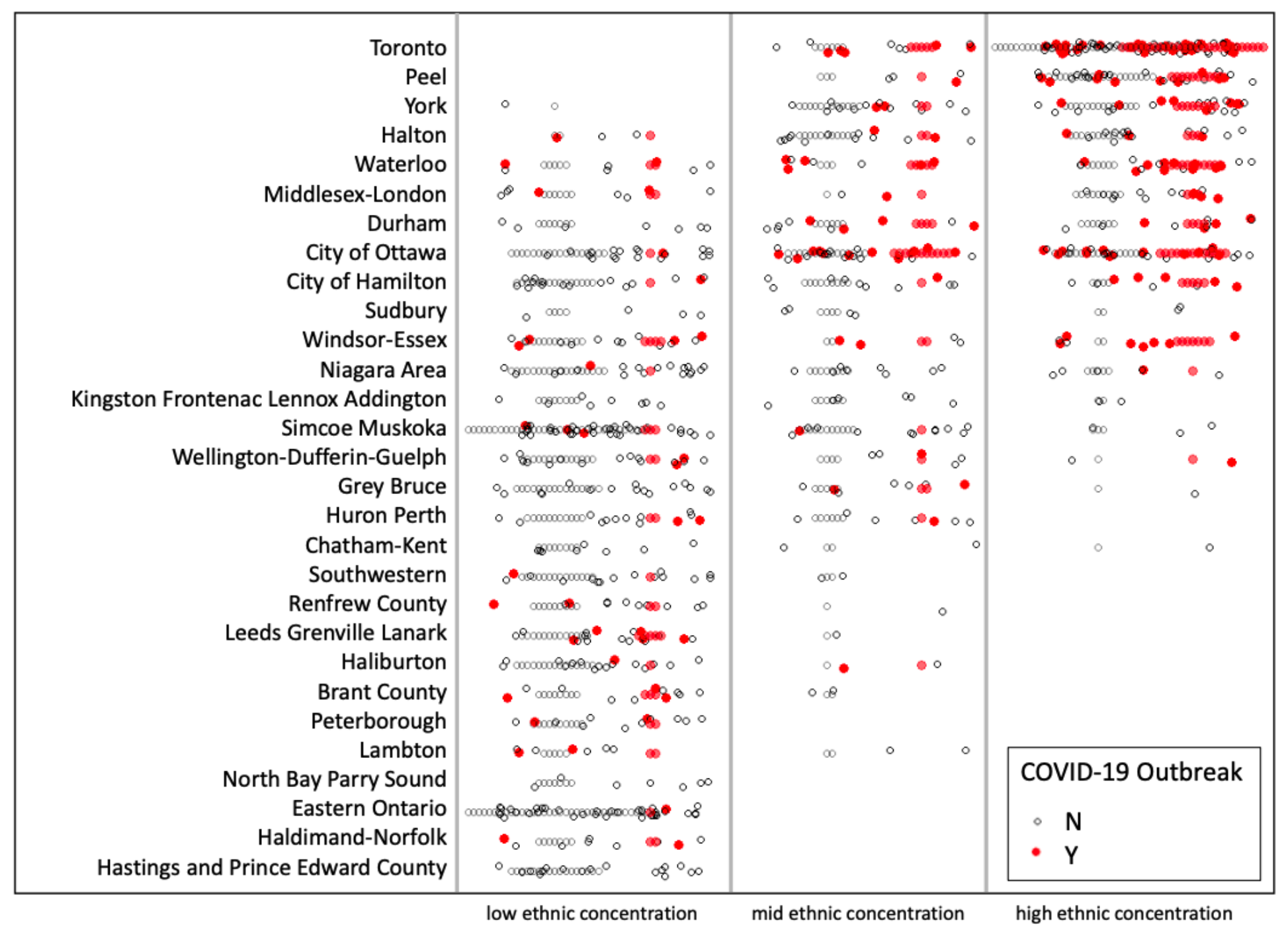

Figure 1. Retirement Home COVID-19 Outbreaks by Community-level Ethnic Concentration and Public Health Unit Region, Ontario, Mar 1-Sep. 24 2020. Public health unit regions with less than 5 retirement homes are excluded. 


\section{Appendix 1: 13 Care Services Available to Residents (Directly or Indirectly)}

\section{Services}

Assistance with personal hygiene

Assistance with bathing

Assistance with dressing

Assistance with ambulation

Assistance with feeding

Meal provision

Medication administration

Dementia care program

Continence care

Skin and wound care program

Nursing services*

Medical services^

Pharmacy services

*Any service that a member of the College of Nurses of Ontario provides while engaging in the practice of nursing.

$\wedge$ Any service that a member of the College of Physicians and Surgeons of Ontario provides while engaging in the practice of medicine.

Any service that a member of the Ontario College of Pharmacists provides while engaging in the practice of pharmacy. 
Appendix 2: The RECORD statement - checklist of items, extended from the STROBE statement, that should be reported in observational studies using routinely collected health data

\begin{tabular}{|c|c|c|c|c|c|}
\hline & $\begin{array}{l}\text { Item } \\
\text { No. }\end{array}$ & STROBE items & $\begin{array}{l}\text { Location in } \\
\text { manuscript where } \\
\text { items are } \\
\text { reported }\end{array}$ & RECORD items & $\begin{array}{l}\text { Location in } \\
\text { manuscript } \\
\text { where items } \\
\text { are reported }\end{array}$ \\
\hline \multicolumn{6}{|c|}{ Title and abstract } \\
\hline & 1 & $\begin{array}{l}\text { (a) Indicate the study's } \\
\text { design with a commonly } \\
\text { used term in the title or the } \\
\text { abstract (b) Provide in the } \\
\text { abstract an informative and } \\
\text { balanced summary of what } \\
\text { was done and what was } \\
\text { found }\end{array}$ & $\begin{array}{l}1 \text { (a) Included, } \\
\text { abstract } \\
\text { (methods) } \\
1 \text { (b) Included, } \\
\text { abstract } \\
\text { (methods, results, } \\
\text { conclusion) }\end{array}$ & $\begin{array}{l}\text { RECORD 1.1: The type of data used } \\
\text { should be specified in the title or } \\
\text { abstract. When possible, the name } \\
\text { of the databases used should be } \\
\text { included. } \\
\text { RECORD 1.2: If applicable, the } \\
\text { geographic region and timeframe } \\
\text { within which the study took place } \\
\text { should be reported in the title or } \\
\text { abstract. } \\
\text { RECORD 1.3: If linkage between } \\
\text { databases was conducted for the } \\
\text { study, this should be clearly stated } \\
\text { in the title or abstract. }\end{array}$ & $\begin{array}{l}1.1 \text { Included, } \\
\text { abstract } \\
\text { (methods) } \\
1.2 \text { Included, } \\
\text { title and } \\
\text { abstract } \\
\text { (methods, } \\
\text { results) } \\
1.3 \mathrm{~N} / \mathrm{A}\end{array}$ \\
\hline \multicolumn{6}{|l|}{ Introduction } \\
\hline $\begin{array}{l}\text { Background } \\
\text { rationale }\end{array}$ & 2 & $\begin{array}{l}\text { Explain the scientific } \\
\text { background and rationale for } \\
\text { the investigation being } \\
\text { reported }\end{array}$ & $\begin{array}{l}\text { Included, } \\
\text { introduction }\end{array}$ & & \\
\hline Objectives & 3 & $\begin{array}{l}\text { State specific objectives, } \\
\text { including any prespecified }\end{array}$ & $\begin{array}{l}\text { Included, } \\
\text { introduction }\end{array}$ & & \\
\hline
\end{tabular}




\begin{tabular}{|c|c|c|c|c|c|}
\hline & & hypotheses & & & \\
\hline \multicolumn{6}{|l|}{ Methods } \\
\hline Study Design & 4 & $\begin{array}{l}\text { Present key elements of } \\
\text { study design early in the } \\
\text { paper }\end{array}$ & Included, Methods & & \\
\hline Setting & 5 & $\begin{array}{l}\text { Describe the setting, } \\
\text { locations, and relevant } \\
\text { dates, including periods of } \\
\text { recruitment, exposure, } \\
\text { follow-up, and data } \\
\text { collection }\end{array}$ & Included, Methods & & \\
\hline Participants & 6 & $\begin{array}{l}\text { (a) Cohort study-Give the } \\
\text { eligibility criteria, and the } \\
\text { sources and methods of } \\
\text { selection of participants. } \\
\text { Describe methods of follow- } \\
\text { up } \\
\text { Case-control study - Give the } \\
\text { eligibility criteria, and the } \\
\text { sources and methods of case } \\
\text { ascertainment and control } \\
\text { selection. Give the rationale } \\
\text { for the choice of cases and } \\
\text { controls } \\
\text { Cross-sectional study-Give } \\
\text { the eligibility criteria, and } \\
\text { the sources and methods of } \\
\text { selection of participants } \\
\text { (b) Cohort study-For }\end{array}$ & $\begin{array}{l}6 \text { (a) Included, } \\
\text { Methods }\end{array}$ & $\begin{array}{l}\text { RECORD 6.1: The methods of study } \\
\text { population selection (such as codes } \\
\text { or algorithms used to identify } \\
\text { subjects) should be listed in detail. } \\
\text { If this is not possible, an } \\
\text { explanation should be provided. } \\
\text { RECORD 6.2: Any validation studies } \\
\text { of the codes or algorithms used to } \\
\text { select the population should be } \\
\text { referenced. If validation was } \\
\text { conducted for this study and not } \\
\text { published elsewhere, detailed } \\
\text { methods and results should be } \\
\text { provided. } \\
\text { RECORD 6.3: If the study involved } \\
\text { linkage of databases, consider use } \\
\text { of a flow diagram or other }\end{array}$ & $\begin{array}{l}6.1 \text { Included, } \\
\text { Methods } \\
6.2 \text { Not } \\
\text { Included, data } \\
\text { source was not } \\
\text { validated - this } \\
\text { limitation was } \\
\text { highlighted in } \\
\text { the discussion } \\
\text { 6.3 N/A, no data } \\
\text { linkages }\end{array}$ \\
\hline
\end{tabular}




\begin{tabular}{|c|c|c|c|c|c|}
\hline & & $\begin{array}{l}\text { matched studies, give } \\
\text { matching criteria and } \\
\text { number of exposed and } \\
\text { unexposed } \\
\text { Case-control study - For } \\
\text { matched studies, give } \\
\text { matching criteria and the } \\
\text { number of controls per case }\end{array}$ & & $\begin{array}{l}\text { graphical display to demonstrate } \\
\text { the data linkage process, including } \\
\text { the number of individuals with } \\
\text { linked data at each stage. }\end{array}$ & \\
\hline Variables & 7 & $\begin{array}{l}\text { Clearly define all outcomes, } \\
\text { exposures, predictors, } \\
\text { potential confounders, and } \\
\text { effect modifiers. Give } \\
\text { diagnostic criteria, if } \\
\text { applicable. }\end{array}$ & Included, Methods & $\begin{array}{l}\text { RECORD 7.1: A complete list of } \\
\text { codes and algorithms used to } \\
\text { classify exposures, outcomes, } \\
\text { confounders, and effect modifiers } \\
\text { should be provided. If these cannot } \\
\text { be reported, an explanation should } \\
\text { be provided. }\end{array}$ & $\begin{array}{l}\text { N/A, no codes } \\
\text { or algorithms } \\
\text { needed for } \\
\text { ascertainment } \\
\text { of exposure, } \\
\text { outcomes, } \\
\text { confounders, } \\
\text { and effect } \\
\text { modifiers }\end{array}$ \\
\hline $\begin{array}{l}\text { Data sources/ } \\
\text { measurement }\end{array}$ & 8 & $\begin{array}{l}\text { For each variable of interest, } \\
\text { give sources of data and } \\
\text { details of methods of } \\
\text { assessment (measurement). } \\
\text { Describe comparability of } \\
\text { assessment methods if there } \\
\text { is more than one group }\end{array}$ & Included, Methods & & \\
\hline Bias & 9 & $\begin{array}{l}\text { Describe any efforts to } \\
\text { address potential sources of } \\
\text { bias }\end{array}$ & Included, Methods & & \\
\hline Study size & 10 & $\begin{array}{l}\text { Explain how the study size } \\
\text { was arrived at }\end{array}$ & Included, Methods & & \\
\hline $\begin{array}{l}\text { Quantitative } \\
\text { variables }\end{array}$ & 11 & $\begin{array}{l}\text { Explain how quantitative } \\
\text { variables were handled in }\end{array}$ & Included, Methods & & \\
\hline
\end{tabular}




\begin{tabular}{|c|c|c|c|c|c|}
\hline & & $\begin{array}{l}\text { the analyses. If applicable, } \\
\text { describe which groupings } \\
\text { were chosen, and why }\end{array}$ & & & \\
\hline $\begin{array}{l}\text { Statistical } \\
\text { methods }\end{array}$ & 12 & $\begin{array}{l}\text { (a) Describe all statistical } \\
\text { methods, including those } \\
\text { used to control for } \\
\text { confounding } \\
\text { (b) Describe any methods } \\
\text { used to examine subgroups } \\
\text { and interactions } \\
\text { (c) Explain how missing data } \\
\text { were addressed } \\
\text { (d) Cohort study - If } \\
\text { applicable, explain how loss } \\
\text { to follow-up was addressed } \\
\text { Case-control study - If } \\
\text { applicable, explain how } \\
\text { matching of cases and } \\
\text { controls was addressed } \\
\text { Cross-sectional study - If } \\
\text { applicable, describe } \\
\text { analytical methods taking } \\
\text { account of sampling strategy } \\
\text { (e) Describe any sensitivity } \\
\text { analyses }\end{array}$ & $\begin{array}{l}12 \text { (a) Included, } \\
\text { Methods } \\
\text { (statistical } \\
\text { analysis) } \\
12 \text { (b) N/A, no } \\
\text { subgroups or } \\
\text { interactions } \\
\text { examined } \\
12 \text { (c) No missing } \\
\text { data. } \\
12 \text { (d) N/A (no loss } \\
\text { to follow-up) } \\
12 \text { (e) None } \\
\text { performed. }\end{array}$ & & \\
\hline Data access and & & .. & & RECORD 12.1: Authors should & 12.1 Included, \\
\hline
\end{tabular}




\begin{tabular}{|c|c|c|c|c|c|}
\hline $\begin{array}{l}\text { cleaning } \\
\text { methods }\end{array}$ & & & & $\begin{array}{l}\text { describe the extent to which the } \\
\text { investigators had access to the } \\
\text { database population used to create } \\
\text { the study population. } \\
\text { RECORD 12.2: Authors should } \\
\text { provide information on the data } \\
\text { cleaning methods used in the } \\
\text { study. }\end{array}$ & $\begin{array}{l}\text { Methods } \\
\text { (Provincial } \\
\text { Modelling } \\
\text { Table) } \\
\text { 12.2 N/A, no } \\
\text { data cleaning } \\
\text { performed }\end{array}$ \\
\hline Linkage & & .. & & $\begin{array}{l}\text { RECORD 12.3: State whether the } \\
\text { study included person-level, } \\
\text { institutional-level, or other data } \\
\text { linkage across two or more } \\
\text { databases. The methods of linkage } \\
\text { and methods of linkage quality } \\
\text { evaluation should be provided. }\end{array}$ & $\begin{array}{l}\text { Included, } \\
\text { Methods } \\
\text { (institutional- } \\
\text { level data used } \\
\text { and there were } \\
\text { no linkages) }\end{array}$ \\
\hline \multicolumn{6}{|l|}{ Results } \\
\hline Participants & 13 & $\begin{array}{l}\text { (a) Report the numbers of } \\
\text { individuals at each stage of } \\
\text { the study (e.g., numbers } \\
\text { potentially eligible, } \\
\text { examined for eligibility, } \\
\text { confirmed eligible, included } \\
\text { in the study, completing } \\
\text { follow-up, and analysed) } \\
\text { (b) Give reasons for non- } \\
\text { participation at each stage. } \\
\text { (c) Consider use of a flow } \\
\text { diagram }\end{array}$ & $\begin{array}{l}13(\mathrm{a}-\mathrm{c}) \mathrm{N} / \mathrm{A} \text {, all } \\
\text { Ontario RH homes } \\
\text { included with no } \\
\text { loss to follow-up }\end{array}$ & $\begin{array}{l}\text { RECORD 13.1: Describe in detail } \\
\text { the selection of the persons } \\
\text { included in the study (i.e., study } \\
\text { population selection) including } \\
\text { filtering based on data quality, data } \\
\text { availability and linkage. The } \\
\text { selection of included persons can } \\
\text { be described in the text and/or by } \\
\text { means of the study flow diagram. }\end{array}$ & $\begin{array}{l}\text { N/A, no } \\
\text { selection of } \\
\text { persons in the } \\
\text { study }\end{array}$ \\
\hline Descriptive data & 14 & $\begin{array}{l}\text { (a) Give characteristics of } \\
\text { study participants (e.g., }\end{array}$ & $\begin{array}{l}14 \text { (a) N/A, no RH } \\
\text { resident }\end{array}$ & & \\
\hline
\end{tabular}




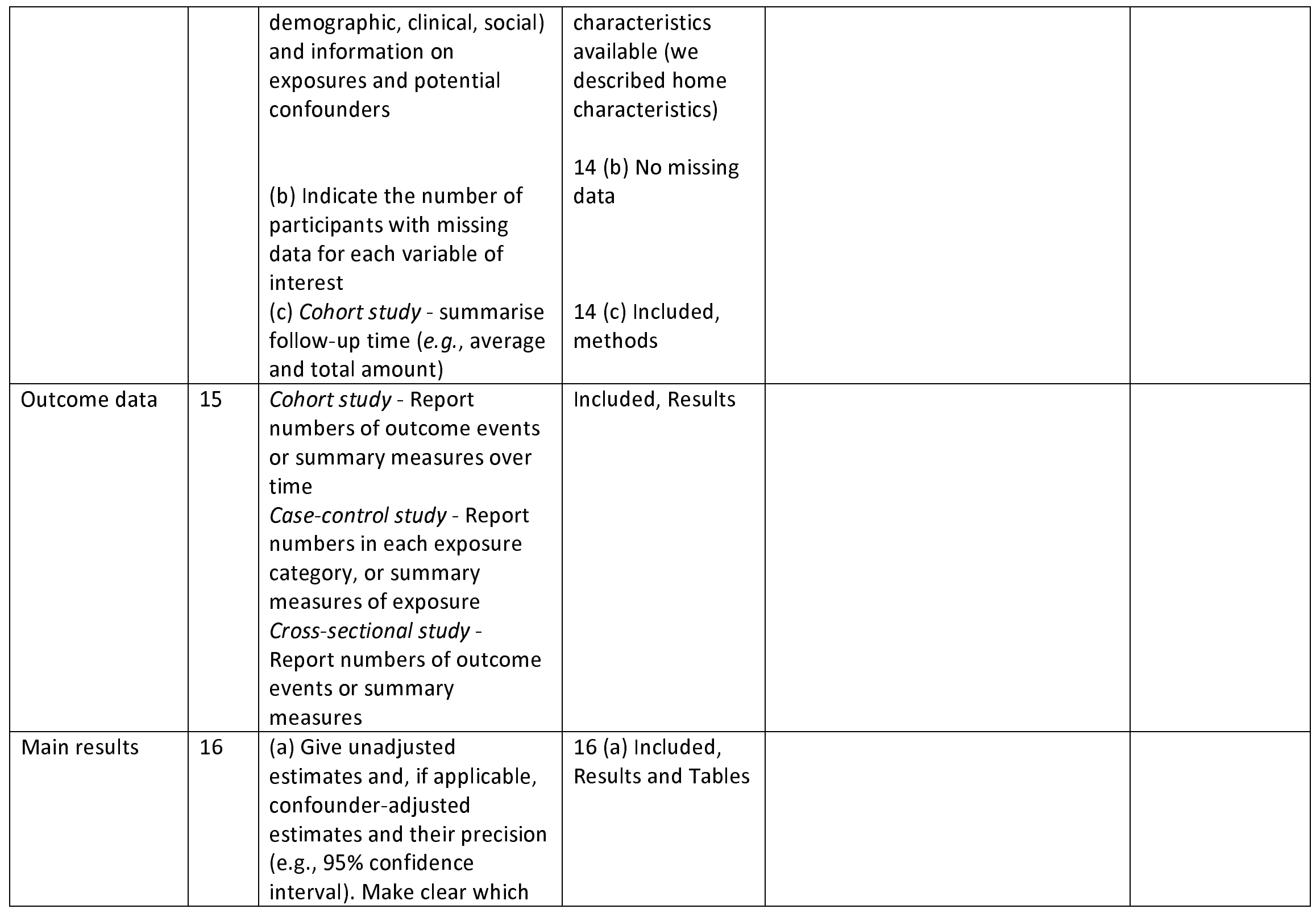




\begin{tabular}{|c|c|c|c|c|c|}
\hline & & $\begin{array}{l}\text { confounders were adjusted } \\
\text { for and why they were } \\
\text { included } \\
\text { (b) Report category } \\
\text { boundaries when continuous } \\
\text { variables were categorized } \\
\text { (c) If relevant, consider } \\
\text { translating estimates of } \\
\text { relative risk into absolute } \\
\text { risk for a meaningful time } \\
\text { period }\end{array}$ & $\begin{array}{l}16 \text { (b) Included, } \\
\text { Results and Tables } \\
16 \text { (c) Included, } \\
\text { Results and Tables }\end{array}$ & & \\
\hline Other analyses & 17 & $\begin{array}{l}\text { Report other analyses } \\
\text { done-e.g., analyses of } \\
\text { subgroups and interactions, } \\
\text { and sensitivity analyses }\end{array}$ & $\begin{array}{l}\text { N/A (no other } \\
\text { analyses) }\end{array}$ & & \\
\hline \multicolumn{6}{|l|}{ Discussion } \\
\hline Key results & 18 & $\begin{array}{l}\text { Summarise key results with } \\
\text { reference to study objectives }\end{array}$ & $\begin{array}{l}\text { Included, } \\
\text { Discussion }\end{array}$ & & \\
\hline Limitations & 19 & $\begin{array}{l}\text { Discuss limitations of the } \\
\text { study, taking into account } \\
\text { sources of potential bias or } \\
\text { imprecision. Discuss both } \\
\text { direction and magnitude of } \\
\text { any potential bias }\end{array}$ & $\begin{array}{l}\text { Included, } \\
\text { Discussion }\end{array}$ & $\begin{array}{l}\text { RECORD 19.1: Discuss the } \\
\text { implications of using data that } \\
\text { were not created or collected to } \\
\text { answer the specific research } \\
\text { question(s). Include discussion of } \\
\text { misclassification bias, unmeasured } \\
\text { confounding, missing data, and } \\
\text { changing eligibility over time, as } \\
\text { they pertain to the study being } \\
\text { reported. }\end{array}$ & $\begin{array}{l}\text { Included, } \\
\text { Discussion } \\
\text { (paragraph on } \\
\text { limitations) }\end{array}$ \\
\hline Interpretation & 20 & Give a cautious overall & Included, & & \\
\hline
\end{tabular}




\begin{tabular}{|c|c|c|c|c|c|}
\hline & & $\begin{array}{l}\text { interpretation of results } \\
\text { considering objectives, } \\
\text { limitations, multiplicity of } \\
\text { analyses, results from similar } \\
\text { studies, and other relevant } \\
\text { evidence }\end{array}$ & Conclusion & & \\
\hline Generalisability & 21 & $\begin{array}{l}\text { Discuss the generalisability } \\
\text { (external validity) of the } \\
\text { study results }\end{array}$ & $\begin{array}{l}\text { Included, } \\
\text { Discussion }\end{array}$ & & \\
\hline \multicolumn{6}{|c|}{ Other Information } \\
\hline Funding & 22 & $\begin{array}{l}\text { Give the source of funding } \\
\text { and the role of the funders } \\
\text { for the present study and, if } \\
\text { applicable, for the original } \\
\text { study on which the present } \\
\text { article is based }\end{array}$ & $\begin{array}{l}\text { N/A, study was } \\
\text { not funded. } \\
\text { Funding of } \\
\text { individual } \\
\text { researcher } \\
\text { detailed in the } \\
\text { Acknowledgement } \\
\text { s section }\end{array}$ & & \\
\hline $\begin{array}{l}\text { Accessibility of } \\
\text { protocol, raw } \\
\text { data, and } \\
\text { programming } \\
\text { code }\end{array}$ & & .. & & $\begin{array}{l}\text { RECORD 22.1: Authors should } \\
\text { provide information on how to } \\
\text { access any supplemental } \\
\text { information such as the study } \\
\text { protocol, raw data, or } \\
\text { programming code. }\end{array}$ & $\begin{array}{l}\text { Included, } \\
\text { Acknowledgem } \\
\text { ents Section }\end{array}$ \\
\hline
\end{tabular}


Appendix 3: Rolling 14-day COVID-10 case count, by Public Health Unit Region, Ontario, Mar 1-Sep. 242020

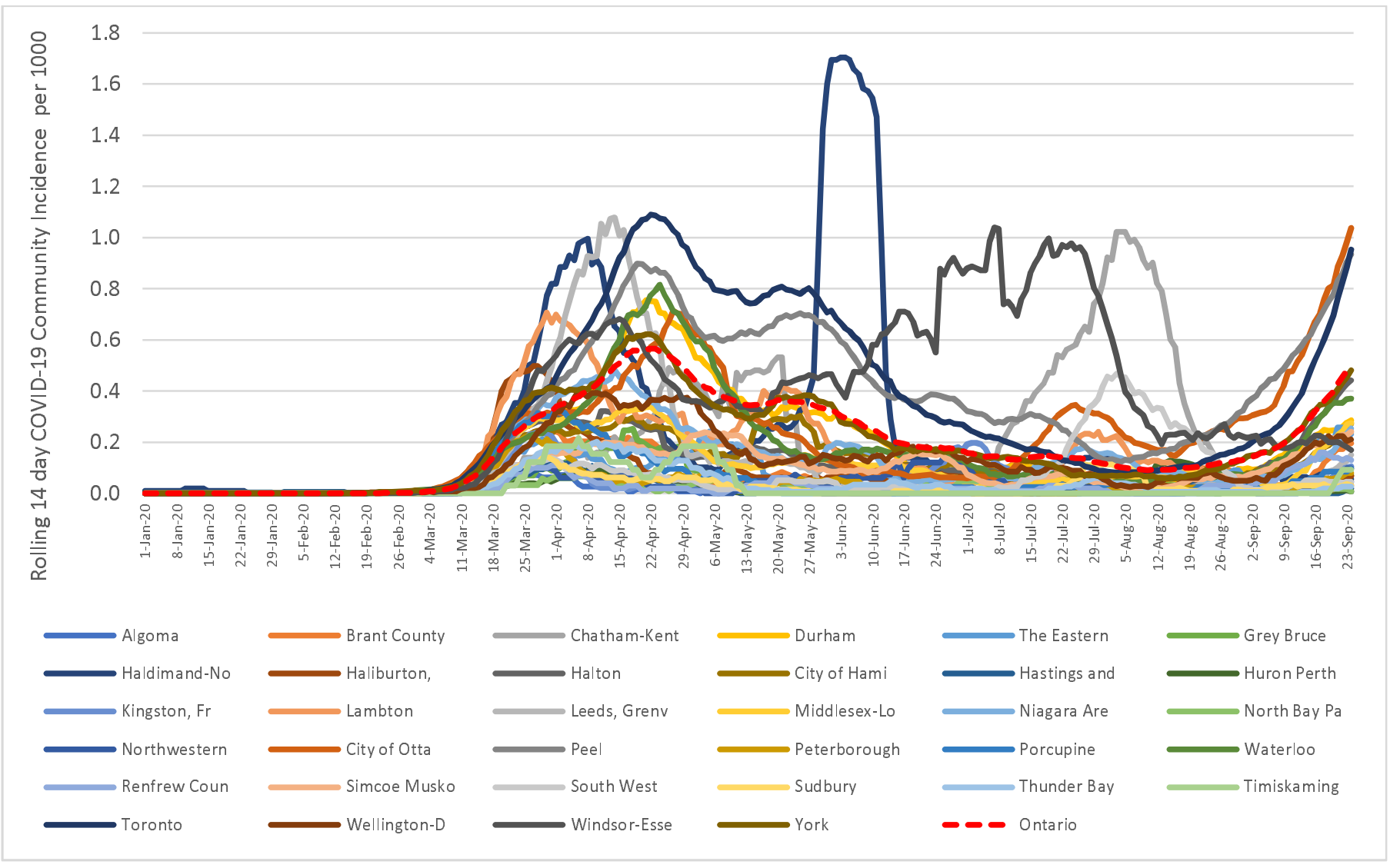




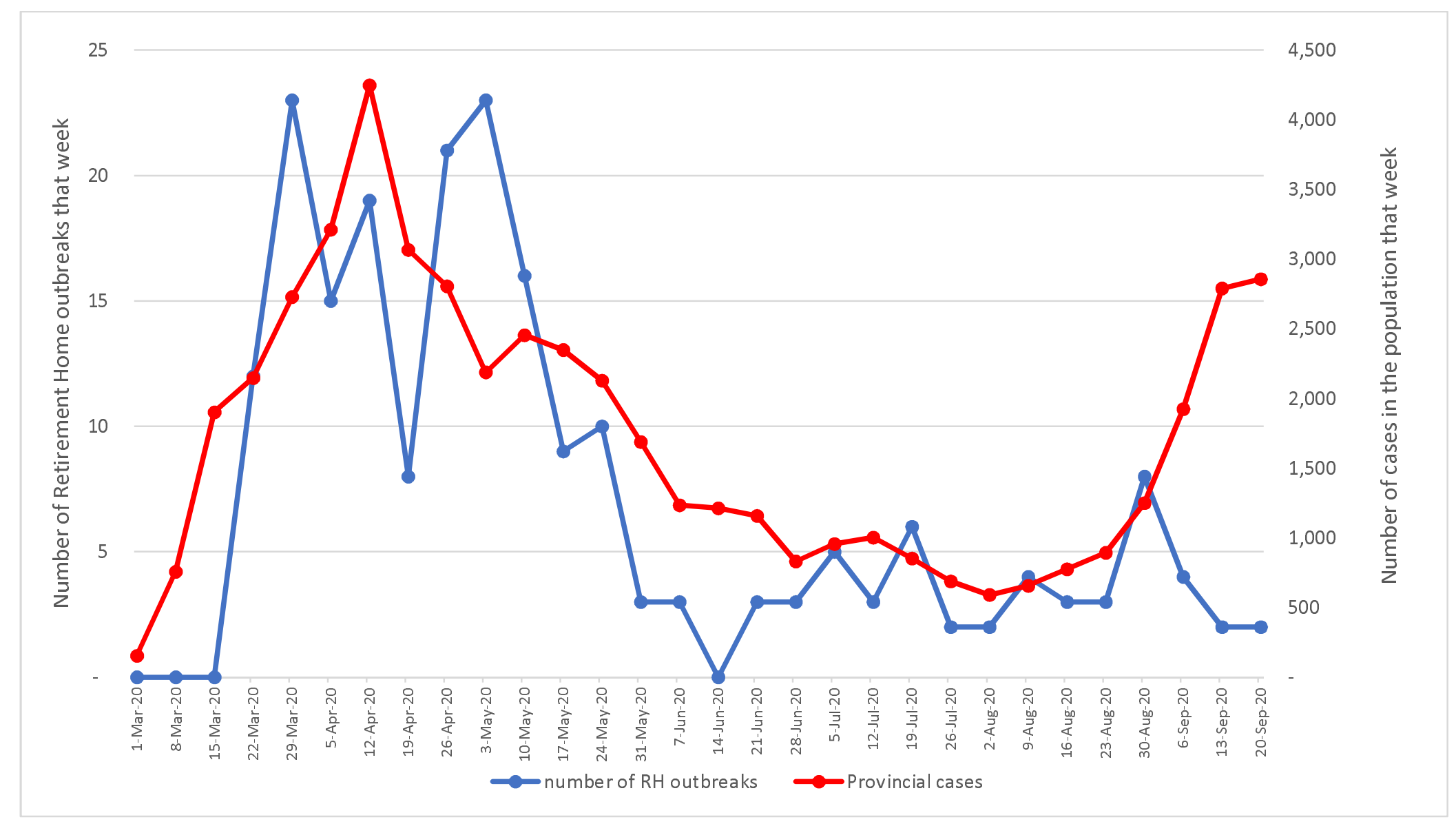


Appendix 5: Cumulative Count of Retirement Home COVID-19 Cases and Deaths, Ontario, Mar 1-Sep. 242020 (N=770 facilities)

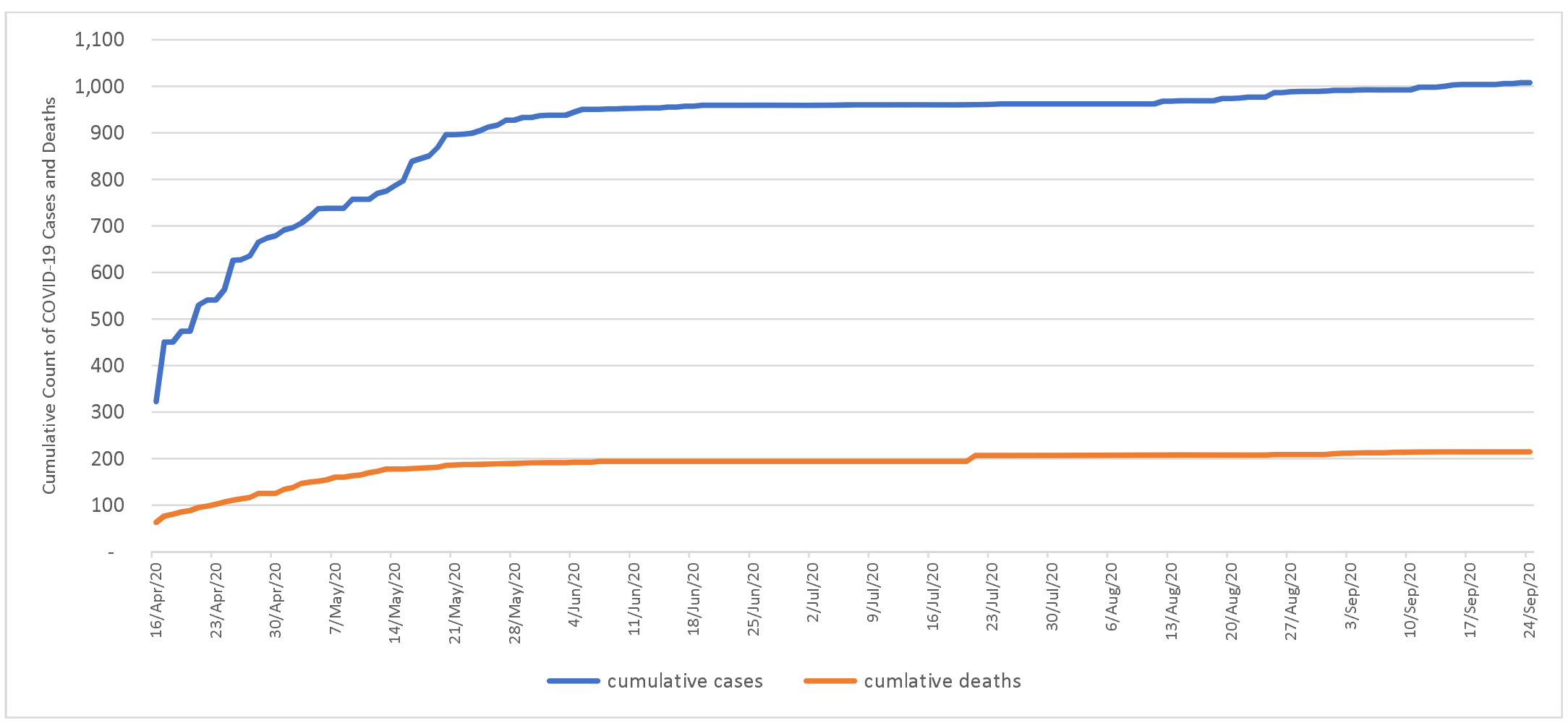

